\title{
Miranda
}

Revue pluridisciplinaire du monde anglophone /

Multidisciplinary peer-reviewed journal on the English-

speaking world

$14 \mid 2017$

Early American Surrealisms, 1920-1940 / Parable Art

\section{Celebrating Susan Glaspell and Trifles in Spain}

A Review of the Exhibition "Susan Glaspell (1876-1948): pionera del teatro experimental. Trifles, los Provincetown Players y el teatro de vanguardia" ("Susan Glaspell (1876-1948): The Pioneer of Experimental Theatre. Trifles, the Provincetown Players and the Avant-garde Theatre")

Quetzalina Lavalle Salvatori

\section{OpenEdition}

\section{Journals}

Electronic version

URL: http://journals.openedition.org/miranda/10102

DOI: 10.4000/miranda.10102

ISSN: 2108-6559

Publisher

Université Toulouse - Jean Jaurès

\section{Electronic reference}

Quetzalina Lavalle Salvatori, "Celebrating Susan Glaspell and Trifles in Spain", Miranda [Online], 14 |

2017, Online since 18 April 2017, connection on 16 February 2021. URL: http://

journals.openedition.org/miranda/10102 ; DOI: https://doi.org/10.4000/miranda.10102

This text was automatically generated on 16 February 2021



Miranda is licensed under a Creative Commons Attribution-NonCommercial-NoDerivatives 4.0 International License. 


\section{Celebrating Susan Glaspell and Trifles in Spain}

A Review of the Exhibition "Susan Glaspell (1876-1948): pionera del teatro experimental. Trifles, los Provincetown Players y el teatro de vanguardia" ("Susan Glaspell (1876-1948): The Pioneer of Experimental Theatre. Trifles, the Provincetown Players and the Avant-garde Theatre")

Quetzalina Lavalle Salvatori

\section{The International Susan Glaspell Society: Website}

1 http://blogs.shu.edu/glaspellsociety/ 
[Figure 1]

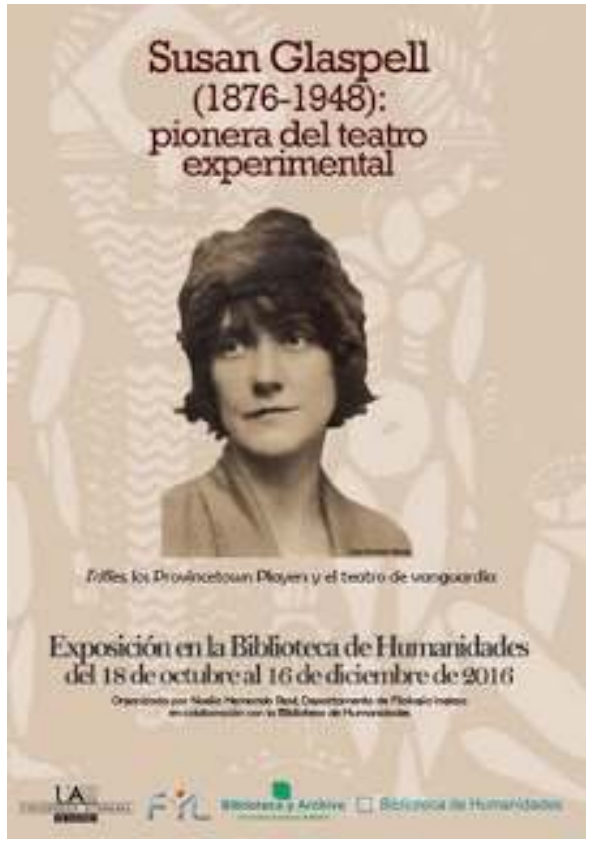

Poster design by Noelia Hernando Real; photography by Nicholas Murray.

\section{Susan Glaspell, Trifles and the Hossack Case}

Susan Glaspell was born in 1876 in Davenport, Iowa. Although growing in a rural environment, she became a young lady with strong and challenging ideas. She went to Drake University, where she graduated in Philosophy in 1899. After that she became a reporter for the Des Moines Daily News, where she covered the legislature and law section. Following her desire to be a writer, she started writing short stories and novels, becoming quite successful. Nevertheless, it was in the theatre where Susan Glaspell excelled herself. Soon after marrying George Cram Cook, they co-founded the Provincetown Players, a revolutionary theatre group that achieved an innovative and truly American theatre, far away from European models and the conventional Naturalism or Melodrama so popular back then on Broadway. Eugene O'Neill, known as the father of American theatre, or Robert Edmond Jones, the famous scenic designer, were some of the figures that belonged to the group; without forgetting Glaspell, who, if o'Neill is indeed known as the father, shall be considered the mother of the American theatre. She wrote eleven plays with the Provincetown Players, among which is Trifles, a play inspired by the Hossack murder case Glaspell had covered when she worked at the Des Moines Daily News. It was written and performed for the first time in 1916 and nowadays is considered one of her masterpieces.

The Hossack case was a cold blood murder that shocked the Iowa population at the end of 1900. John Hossack, a well-to-do farmer, was mysteriously killed around midnight on the 1st of December while sleeping. The murder weapon was an axe that was later found in the barn of the family property. After discarding the possibility of burglars, the main suspect became Margaret, John's wife. As her husband was tragically killed, she remained next to him, sleeping, without ever waking up. Finally, it was discovered that Margaret was severely abused by John and that the neighbours were well aware of 
it. Mrs. Hossack was eventually detained and judged; she was sentenced to life imprisonment.

Glaspell followed the case from the very beginning, which marked her career as a writer and her fight as a feminist. As new evidence was discovered, her opinion changed: once she knew Margaret suffered from gender violence, she started questioning to what extent she was a murderer or a victim. Because of this, Glaspell also believed that, as anybody else, Mrs. Hossack deserved a jury of her peers; women who could understand her situation better than men. However, women were not allowed to sit on juries (until 1920 in Iowa). These thoughts led Glaspell to write Trifles, a play in one act in which Minnie Wright, accused of murdering her husband, received a fair trial by two of her neighbours, Mrs. Hale and Mrs. Peter, who by reading the "trifles" they find in Minnie's kitchen, discover she was mistreated and abused. As a consequence, they comprehend the complexity of her situation and "judge" it accordingly, taking into account facts that their male counterparts would immediately discard.

\section{The Review}

5 In order to commemorate the centennial of this masterpiece, Professor Noelia Hernando Real, currently teaching at the Universidad Autónoma de Madrid (UAM, Spain) and president of the International Susan Glaspell Society, curated the exhibition "Susan Glaspell (1876-1948): pionera del teatro experimental. Trifles, los Provincetown Players y el teatro de vanguardia" ("Susan Glaspell (1876-1948): The Pioneer of Experimental Theatre. Trifles, the Provincetown Players and the Avant-garde Theatre") in the Humanities library of the UAM, located in the Cantoblanco Campus in Madrid. The intention of the exhibition was to celebrate this eminent play, but also to introduce Glaspell and her work to students and the general public who were not familiar with the playwright, as well as to give further information about her life and career to those already acquainted with her art. The display opened on the $18^{\text {th }}$ of October of 2016, coinciding with the seminar "The Politics of Theatre: Susan Glaspell, the Provincetown Players and the Creation of Modern US Drama," also organized by Noelia Hernando Real, in which eminent academics of Glaspell, such as Linda Ben-Zvi, Emeline Jouve and Barbara Ozieblo, commented on the relevance of the playwright in the history of American literature and feminist writing. The place where the exhibition took place was a small space in the library, which was inconvenient if you happen to visit it with a group larger than twenty-five persons, but that normally allowed the visitor to move around rather freely and to take his time in every section. The fact that it was located in the library was a great opportunity to introduce the playwright to a much larger scale, for not only did students of English Studies visit the display (the degree in which, most probably, Glaspell was already mentioned), but also students from other branches of Humanities. On the other hand, the library is situated next to the train station of the campus, which makes the building a space frequently visited not only by other students from various faculties who prefer it as their place for study because of its proximity to the train, but also by persons external to the University who visit the campus, which translated in a possible larger variety of public.

The exhibition consisted of two parts. The first one dealt with the Hossack case. It presented a panoramic of Glaspell's articles for the Des Moines Daily News, pictures and 
some documents on the case. The second part was composed of seven glass displayers, each of which presented objects related with Glaspell's life and literary work, her role in the Provincetown Players and their importance in the sociohistorical and cultural context of the New York of the $20^{\text {th }}$ century.

[Figure 2]

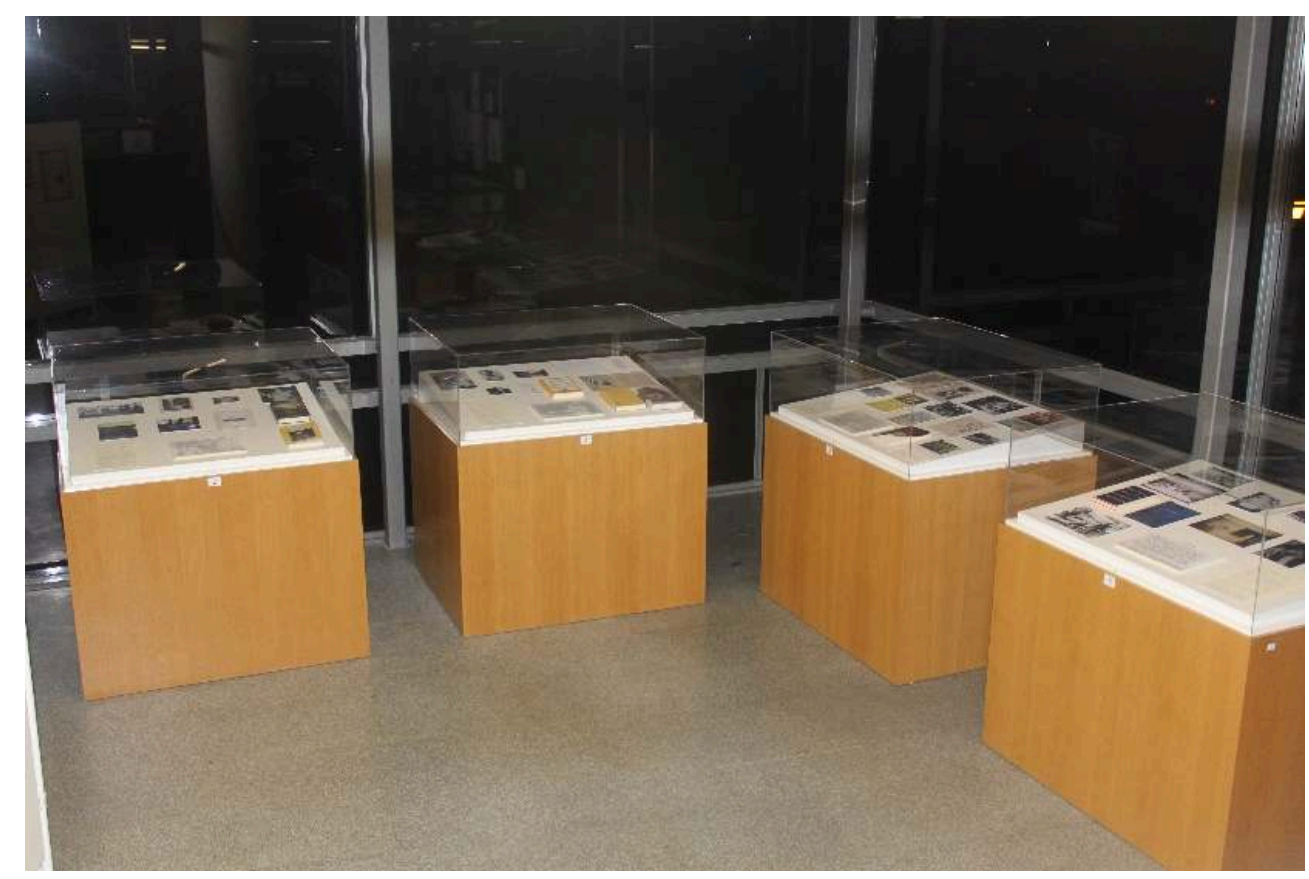

Partial view of the exhibition.

Photography by Quetzalina Lavalle Salvatori

7 The first part served as an introduction to Susan Glaspell and Trifles. It presented nine graphics showing pictures of the Hossack family and farm, a map of the house recreating the steps of the murderer, pictures of Glaspell, and some of her articles on the case. Because the murder was the origin of the play and because Glaspell started writing about it when she was a journalist, it was the ideal way to open the exhibition. On the other hand, the fact that a case of that nature was the inspiration for Trifles is a curious detail that may have called the attention of the visitors who were not familiarized with the theme of the display. The descriptions and commentaries were, comprehensibly, in Spanish. Nevertheless, the articles were in English and the public unable to comprehend the language were not able to read Glaspell's analysis of the case. On the other hand, one of the articles presented was blurry and the understanding of the words was difficult, because of the quality of the scan. A transcription of the texts in Spanish and English would have improved the section, but because of the limited space, it is comprehensible that variety was preferred.

8 The second section was the most relevant part. If the previous one introduced the murder that inspired Trifles, this part developed the information related with the play itself. The first glass cabinet showed pictures of its performance in 1917, and of the original publication of "A Jury of Her Peers" (1917), Glaspell's short story adapted from Trifles and therefore inspired by the Hossack case as well. It also presented publications, films, books, and T.V. series that were based on the play, such as Hitchcock's episode "A Jury of Her Peers" (1961), Midnight Assassin; by Patricia L. Bryan and Thomas Wolf, the 
latest book on Trifles; Martha Carpentier and Emeline Jouve's On Susan Glaspell's Trifles and "A Jury of Her Peers", and several short film adaptations. Together with the items mentioned, links and references to sources were provided when available, giving the public the opportunity to watch or read any of the videos or books if they wished. The description that accompanied the first displayer, entitled "De la realidad a la ficción: El caso Hossack en Glaspell y otros autores," "From fact to fiction: The Hossack case in Glaspell and other authors") mentioned briefly but strongly the importance of the case as a feminist matter that Glaspell, thanks to her play, popularized, and echoed its political and social relevance; this was an indispensable information, for the importance of the playwright and the Provincetown Players' role in the American literature cannot be fully gasped if their introduction of politics into the theatrical scene is not sufficiently stressed. On the other hand, the selection of these particular objects as the opening of the second part seemed ideal: the public was introduced to a play that proved to be influential not only in the $1920 \mathrm{~s}$ but throughout the entire $20^{\text {th }}$ and the beginning of the $21^{\text {st }}$ century.

The second glass cabinet "Susan Glaspell (1876-1948): un espíritu moderno," ("Susan Glaspell (1876-1948): a modern spirit") introduced the early life of the playwright and her beginnings as a writer. Photos of Glaspell as a child and as a young woman, her signature and documents of her time at Drake University were part of this section. Some of her publications as a novelist and as a short story writer were exhibited as well: her first novel The Glory of the Conquered: The Story of a Great Love (1909) and a copy of the magazine in which "The Resurrection and the Life" was published. A photograph of Jig Cook and two biographies of Glaspell were also added to the display. This part centred on her life in Davenport, and from this point onwards the exhibition would take a chronological order following the steps of Glaspell through her life. One of the key parts of this section was the acknowledgement of the popularity and success of Glaspell's short stories, which was illustrated by presenting her publication in The Smart Set magazine, which also printed D.H. Lawrence or Ezra Pound. In this way, the visitor could question why Glaspell is currently a rather unknown author compared to her male fellow writers and grasp the magnitude of her work. In addition, the documents of her time in Drake University and her choice of keeping her last name instead of taking her husband's, demonstrated that she was an example of the "New Woman" who fought for women's education, independence, and rights. The struggle of young Glaspell in a male dominated world is perfectly highlighted by the comment in the description of her signature, which mentioned the anecdote of the New York Times critic who believed that Glaspell's first novel, The Glory of the Conquered, was written by a man under a female pseudonym. The presence of a picture of her love, Jig Cook, introduced the theme of the next displayer, Glaspell's life in New York.

This third section, "Susan Glaspell en Nueva York: el backstage de los Provincetown Players" ("Susan Glaspell in New York: the backstage of the Provincetown Players"), was related with the sociohistorical and cultural context in New York at the beginning of the $20^{\text {th }}$ century. As mentioned before, the relevance of the Provincetown Players and of Glaspell's work cannot be fully understood without being aware of their political commitment. In this case, the Patterson strike and the following Patterson strike pageant; the Armory show and the suffragist movement are the main events showed by means of pictures, posters and articles. Before their meeting in Provincetown, most of the members of the group had already met in New York, in part due to the events mentioned above. The Patterson strike denounced the poor conditions of workers in 
the silk mill factories and demanded new legislations to control children labour and abusive working hours. After the brutal response of the police and in order to raise funds for the strike, John Reed (a picture of him is displayed) decided to organize a big pageant in which artists and workers would join forces. Most of the soon-to-be Provincetown Players participated in the event, among which was Robert Edmund Jones, who designed the official poster (also included in the glass cabinet). Eventually, the strike failed, but the pageant demonstrated that modern art was a strong ally of the labour forces. Further evidence of this was the radical socialist magazine The Masses, in which many artists and intellectuals collaborated: a copy of John Reed's article on the Patterson strike was part of this section of the display. Another event that was deeply influential for the New York artists was the Armory Show, which introduced European modernism in America. This was essential for the development of the Provincetown Players and their unique style, for their experimentation and reformulation of the American theatre had its roots in the principles of modernism. In this section, this is skilfully connected with the Abbey Theatre and its American tour. The Abbey Players, led by Lady Gregory and William Butler Yeats, convinced the young artists in New York that a new kind of American drama needed to be created. Finally, the picture of a demonstration for the female vote reminded the public of the relevance of the feminist movement in Glaspell's work. Indeed, this part of the exhibition is key to the visitor's realization of the significance of Glaspell and the Provincetown Players within the sociohistorical context.

11 The exhibition continued with the introduction to the group itself and their time in Provincetown (from 1915 to 1916). Although all the members of the group lived in New York, their starting point was this small, coastal village where artists went to escape from the suffocating heat of the New York summer. Several images composed this part of the exhibition, entitled "Los Provincetown Players" ("The Provincetown Players"): Glaspell and Cook's cottage, the Wharf theatre where they performed, produced and presented their first plays, and many scenes of the members working in their small and humble but significant theatre. Two books complement the pictures: The Dramatic Imagination (1941) by Edmund Jones and Jig Cook and the Provincetown Players (1982) by Robert K. Sarlós. If it was vital to acknowledge the political background of the Provincetown Players, it is equally necessary to be aware of their origins: far away from the fancy staging, the urgency for the critics' approval and the greed for money that characterised Broadway theatres, the group's sole motivation was the search for a more daring, experimental, American theatrical scene. For that reason, they decided to explore their possibilities in an environment in which they felt free and comfortable to express their artistic convictions. The objects of this section showed the independent and counter-cultural spirit of the group that gave America some of its finest artists, such as Eugene O'Neill, Robert Edmund Jones, and Susan Glaspell. The pictures of the wharf, the simple but powerful sceneries and of the role of the members as playwrights, actors and stagehands showed the commitment of these young intellectuals and the strength of their beliefs.

12 After the summer of 1916, the Provincetown Players decided to move their theatre to New York, where they could present plays the entire year and not only during summers. Their project evolved from a hobby to a serious artistic enterprise. It is during this period that Glaspell and O'Neill were discovered as masters of modernist theatre and were acclaimed by critics and the public. Apart from this, they gave the opportunity to several young artists to show their potential: until their dissolution in 
1922 they were able to bring on stage 97 plays written by 46 different playwrights. "Los Provincetown Players conquistan Nueva York" ("The Provincetown Players conquer New York") analysed their time in the big city, showing their official manifesto, a list of the participants of the group in 1916, one of the circulars sent to the subscribers written by Cook (the theatre survived thanks to the donation of the subscribers, so it was important to maintain them informed), several pictures of representations of Glaspell's and O'Neill's plays, such as Women's Honor, Bernice and The Emperor Jones; and their little Playwrights' Theatre on 133 MacDougal Street. In addition, there was a copy of the New York Times announcing the interim the group was taking in 1922, which was really the end of it. Two books about the relevance of the Provincetown Players were displayed: The Provincetown Players and the Culture of Modernity (2005) by Brenda Murphy and Voces contra la mediocridad: la vanguardia teatral de los Provincetwon Players, 1915-1922 (2014) by Noelia Hernando Real. With this section, the theme of the Provincetown Players came to an end in the exhibition. Consisting of three glass cabinets, the history of the most influential theatrical group that inevitably changed the scene of American theatre is explained in depth: the selection of the pictures and objects, together with the brief but precise descriptions reconstructed the timeline of the Provincetown Players without missing any of its key elements, every item and word created an unmissable panoramic of the group of young artists that led a revolution of the American art. By this point of the exhibition the public was fully aware of the principles and motivations of the Provincetown Players, their innovative and independent spirit and its undeniable role in the creation of a modern, experimental American drama.

13 "Susan Glaspell tras los Provincetown Players" ("Susan Glaspell after the Provincetown Players") explored Glaspell's life and career after her role in the experimental theatre group until her death in 1948. It contains pictures of her time with Cook in Greece, where he died in 1924; her flourishing work as a novelist and her further career as a renowned playwright, presenting copies of her novels Brook Evans (1928), Fugitive's Return (which became a best seller) and of her children's book Cherished and Shared of old (1940). There were also two pictures showing Glaspell later in her life and her commemorative tombstone in the Snow Cemetery. The intention of this section was to demonstrate the relevance of the author outside the Provincetown circle and not only as a playwright, but also as a prose writer who easily competed with writers such as Hemmingway and who met the favour of the public and the critics.

14 Finally, the last glass cabinet, "Susan Glaspell tras Susan Glaspell" "'Susan Glaspell after Susan Glaspell"), explored the legacy and influence of the playwright after her death. For decades, Glaspell and her work were forgotten by the male-dominated canon, relegated to oblivion. Nevertheless, thanks to the second feminist wave her importance in the history of American literature was rediscovered and acknowledged again. The display exemplified this recovery through several publications, anthologies and studies that have focused on Glaspell's persona and career in the last few years. In addition, some pictures of contemporary representations of her plays Trifles, Chains of Dew and The Outside by the Orange Tree Theatre (Richmond, England) in 2008 evidenced the

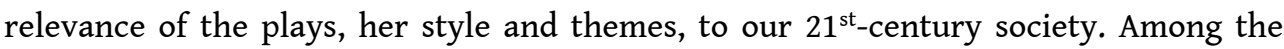
publications, we could find Susan Glaspell. Essays on Her Theatre and Fiction (1995), edited by Linda Ben-Zvi, Susan Glaspell and the Anxiety of Expression (2006), by Kristina HinzBode, and Self and Space in the Theatre of Susan Glaspell (2011), by Noelia Hernando Real. This final part of the exhibition confirmed the public the strong impact Glaspell still 
has in current literary and feminist studies. Furthermore, it demonstrated that her plays convey powerful and solid ideas that our culture and society should reflect on. With this message, the exhibition finished the journey through Glaspell's life and career.

[Figure 3]

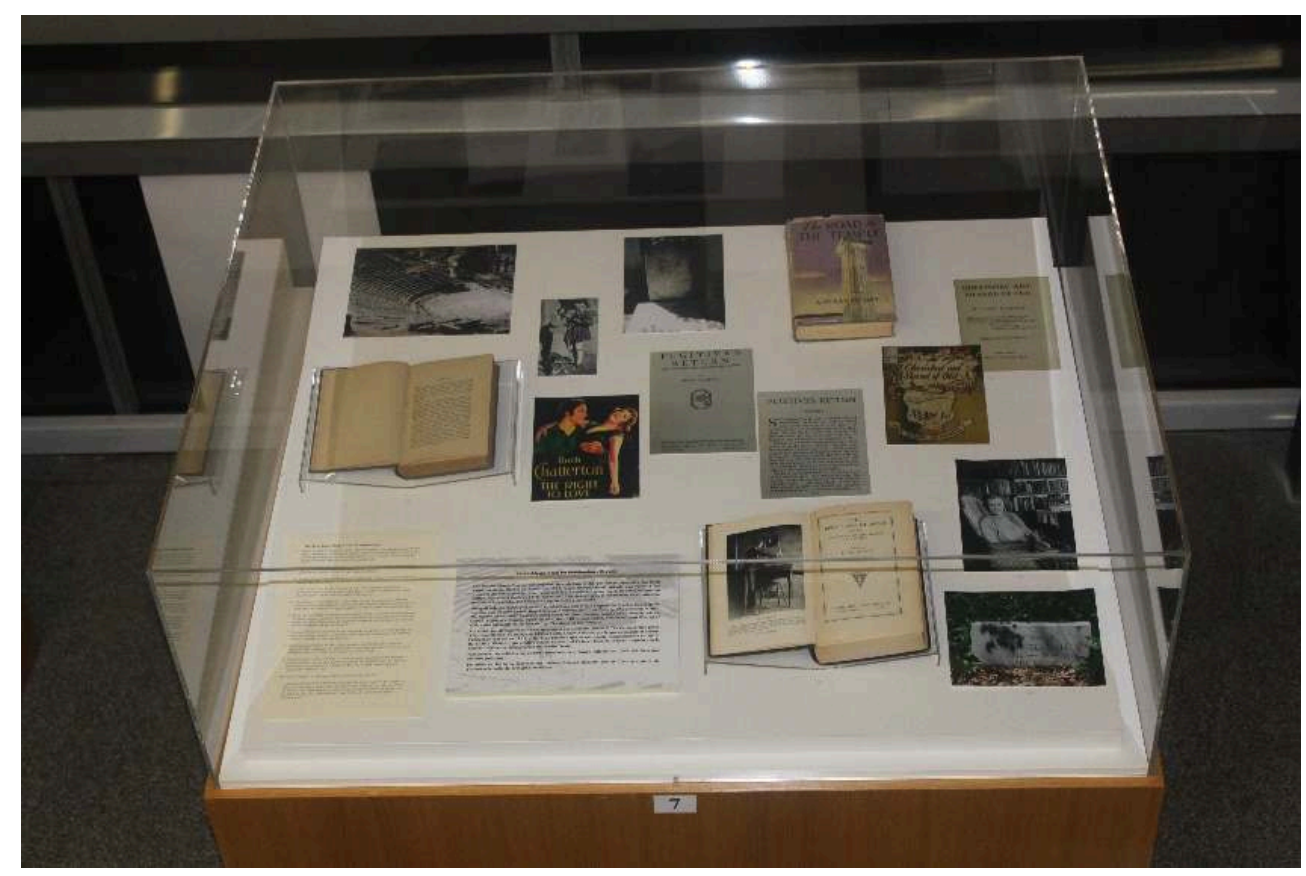

View of "Susan Glaspell tras los Provincetown Players" ("Susan Glaspell after the Provincetown Players").

Credits: photography by Quetzalina Lavalle Salvatori

15 The display as a whole was quite agreeable and informative, it provided a considerable amount of important facts and succeeded in presenting a remarkably complete portrayal of Glaspell in an impressive brevity of time and space. The organization of the themes and the selection of objects were evidently carefully studied and chosen, the descriptions accompanying them were short and concise. The importance given to research and academic writing is outstanding: all the glass displayers were provided with publications related with the theme of each section, allowing the visitors the opportunity to expand their knowledge if they choose to and demonstrating the importance of the academics that brought back Glaspell from the abyss of the forgotten.

16 'Susan Glaspell (1876-1948): pionera del teatro experimental. Trifles, los Provincetown Players y el teatro de vanguardia' was an unmissable appointment for the lovers of theatre and literature, a homage to one of the biggest revolutionaries and builders of the American literary identity, who was lost for a time but that has come back, hopefully to never be missed again. 


\section{ABSTRACTS}

Review of the Exhibition "Susan Glaspell (1876-1948): pionera del teatro experimental. Trifles, los Provincetown Players y el teatro de vanguardia" ("Susan Glaspell (1876-1948): The Pioneer of Experimental Theatre. Trifles, the Provincetown Players and the Avant-garde Theatre") presented in Madrid, Spain, as a celebration of Trifles centennial. The exhibition took place in the Universidad Autónoma de Madrid from October 18th to December 16th 2016.

Critique de l'exposition "Susan Glaspell (1876-1948): pionera del teatro experimental. Trifles, los Provincetown Players y el teatro de vanguardia" (Susan Glaspell (1876-1948): Pionnière du theatre experimental: Trifles, les Provincetown Players et l'avant-garde théâtrale) présenter à Madrid (Espagne) à l'occasion du centenaire de Trifles. L'exposition s'est tenue à l'université Autónoma de Madrid du 18 octobre au 16 décembre 2016.

\section{INDEX}

Mots-clés: Susan Glaspell, littérature, théâtre, théâtre américain, théâtre expérimental, féminisme, auteur de théâtre, avant-garde, Trifles, femmes, Provincetown Players, modernisme, New York, Provincetown

Keywords: Susan Glaspell, literature, theatre, American theatre, experimental theatre, feminism, playwright, avant-garde, Trifles, women, the Provincetown Players, modernism, New York, Provincetown

Subjects: Theater

\section{AUTHOR}

\section{QUETZALINA LAVALLE SALVATORI}

Postgraduate Student

Madrid Masters Degree in English Studies

Universidad Autónoma de Madrid

quetzalina.lavalle@gmail.com 